\title{
Historians, whigs and progress
}

SIR - Edward Harrison's critique of antiwhiggery in the history of science (Nature 329,213 ; 1987) presents a strangely paradoxical discussion of historical inquiry. He describes the anti-whig as a baconian who attempts to investigate the past "with an observant but empty mind". According to this caricature, while historians catalogue the "synchronic events of a particular period", only scientists see "ideas diachronically ... having an effect on later periods".

There is an implicit assumption that the only ordering principle of the history of science is the progress of scientific ideas. but this is precisely the point for which Butterfield justly castigated the whig historians. Harrison approvingly quotes Butterfield's criticism of the whig habit of drawing lines between events that "converge beautifully on the present", but overlooks Butterfield's concern that the whig historian "comes to imagine that [this line] represents something like a line of causation"'.

The whig idea of progress transforms the growth of liberal democracy, or of modern science, from a process to be explained into an explanatory device. But Harrison's great river of science is not just a stream to be mapped at increasingly finer scale; the historian wishes to explain why it takes particular channels and why it sometimes abandons one channel to follow another. For this we must investigate not only its internal dynamics, but also those other factors, the geological structures or vegetative cover, that shaped its flow.

Thus, when anti-whigs document scientists' "family and social lives, travels, accomplishments, publications and awards", these are not isolated facts; rather they mediate and influence the transmission and development of scientific ideas and as such are the meat of historical explanation. The historians' concern with how social, political, religious and other factors shaped scientific institutions and ideas leads to a quite different kind of history from one that focuses on an autonomous cascade of scientific ideas.

Harrison is also troubled lest historians, whose training leaves them ignorant of science, write a history devoid of science and abandon the difficult modern fields for the safer realms of antiquarianism. As to the latter concern, from 1969 to 1986 the portion of items dealing with the nineteenth and twentieth centuries in the chronological section of the Isis Critical Bibliography of the History of Science increased from 46 per cent to 54 per cent, while all other historical periods suffered a decline. One could equally well, or equally fallaciously, argue that this re- flects an unwillingness to contend with the serious historical problems of sources, languages and interpretation that confront the student of early science.

As to the allegation that historians have somehow abandoned the study of that "network of interrelated experiments and theories", one can only note that discussions of the content of science continue to appear, often on the same pages as discussions of its context. To appropriate a line from Harrison, "there is no reason why a history of science cannot combine both views", because as presently practised, it does.

Stephen C. McClunsey

Department of History,

West Virginia University,

Morgantown, West Virginia 26506, USA

1. Butterfield, H. The Whig Interpretation of History, 12 (Horton, New York, 1965)

SIR-Edward Harrison's Commentary attacking "priggish" historians of science assumes that scientists inevitably take a 'whiggish' view of how their discipline has developed. He implies that the blind alleys of scientific investigation are deservedly forgotten. Historians who deliberately try to revive interest in nowrejected theories offer a relativist view of knowledge unacceptable to the scientist. Such claims misrepresent what most historians of science are trying to do and leave scientists free to preserve their blinkered view of the past.

Most historians of science are well aware of the need to show how certain theories became incorporated into the framework of knowledge - only a small contingent of radicals would argue that there is no empirical basis for the success of some theories over others. The problem with whig history is that it often underestimates how long the scientists took to decide what the 'right' position should be. Historians look at 'wrong' (that is, subsequently rejected) theories not to eliminate the distinction between right and wrong, but because we cannot understand how the right one triumphed unless we know why some scientists were at first tempted by the wrong ones.

My own research on non-darwinian evolution theories would probably be classed as a good example of prig history, but it is not my intention to diminish the success of modern darwinism. I merely insist that we cannot ignore the development of evolutionism in the crucial years between the Origin of Species and the emergence of the modern synthetic theory, when most biologists did not accept natural selection. The whig history of evolutionism dismisses lamarckism and other non-darwinian concepts as minor aberrations, but in so doing it (1) ignores the work of a whole generation of biologists, (2) endorses an oversimplified view of the cultural impact of evolutionism and (3) creates artificial puzzlement over questions such as 'Why was Mendel ignored?' The priggish historian looks at the 'false' theories dismissed by the whig interpretation and shows that Mendel was ignored because a whole generation of biologists accepted a non-darwinian and non-mendelian view of evolution and heredity.

Scientists have a legitimate right to focus on certain lines of theoretical development which hindsight tells us were important, but all too often this technique has been used to dismiss as irrelevant everything that was not on the 'main line'. Historians of science oppose whig history because they know that if we do not take the 'blind alleys' seriously, we shall never understand the real structure of the main line itself.

Department of History and

Peter J. Bowler

Philosophy of Science,

The Queen's University of Belfast,

Belfast BT7 1NN, UK

\section{Undoing apartheid}

SIR-J.G. Wilson (Nature 328, 288; 1987) is misinformed. As your survey (Nature 327, 259; 1987) makes clear, black South Africans are not "denied the possibility of a scientific education and career". I visited South Africa recently and can confirm that there are many "non-white" students at the University of the Witwatersrand. And a student who worked here this summer received his degree in electrical engineering from the University of Stellenbosch, in spite of his being classified as "coloured" by the South African government.

In my view, Professor Phillip Tobias and his like-minded colleagues, who make no "secret" of their abhorrence of apartheid, should be invited to international meetings to receive gold medals for the work they are doing to dismantle apartheid in South African Universities.

Roger BURNSIDE

Arecibo Observatory,

PO Box 995 ,

Arecibo, Puerto Rico 00613, USA

\section{Credit where it's due}

SIR - I note with interest and wonder at the reasons why authors in your journal and others so seldom acknowledge help obtained from library and information services while according fulsome praise to typists, photographers, graphics artists, technical assistants, colleagues and practically everyone else.

Judith PALMER

Rothamsted Experimental Station, Harpenden, Herts AL5 2JQ, UK 